\title{
A Pragma-stylistic-assessment of Three Translations of the Meanings of Surratt Fatir into English
}

\author{
Ali Albashir Mohammed \\ King Khalid University, Kingdom of Saudi Arabia \\ Majda Babiker Ahmed \\ King Khalid University, Kingdom of Saudi Arabia \\ Dina Ali Abdullah \\ King Khalid University, Kingdom of Saudi Arabia
}

\begin{abstract}
The current paper aims at investigating the stylistic constrains encounter the translators of the Holy Qura'n into English, through analysis and comparison, the incongruities and disparities of meaning and style in translating the Qur'anic pragama- stylistic expressions into English, that is in the work of Mohammed Abdel Haleem, Pickthall and Mohammed Khan and Taj Al-Din Al-Hilalim (.http://www.aijcrnet.com/journal/index/1128.The study found that different translation strategies could lead to different translated versions of the same Qur'anic pragama-stylistics. Also, Qur'anic pragma-stylistic differences between Arabic and English languages seem to give rise to mistranslations as far as the religious text of Qur'anic texts. It is hoped that the study will cast new light on main important idea that the translators of the Holy Qur'an should consult the main books of exegesis, linguistics, philosophy, intertextuality, jurisprudence and history, etc., when he/she tries to render the Qur'anic prgama-stylistics.
\end{abstract}

Index Terms -A pragma-stylistic, assessment, Fatir, Qur'an, texts texts, strategies, mistranslations

\section{INTRODUCTION}

The current paper is a pragama- stylistic study which aims at investigating the stylistic constrains encounter the translators of the Holy Qura'n into English.

\section{A. Objectives of the Study}

The study aims at:

a. analyzing the pragma-Stylistic-problems and constraints, encountered by translators while rendering the Holy Qur'an into English.

b. identifying these pragma-Stylistic constraints that the translators face.

c. investigating the strategies used by Abdel-Haleem, Pickthall, Khan, and Hilali in rendering rhetorical expressions in some selected ayahs of the Holy Qur'an..

\section{B. Questions of the Study}

To meet the stated objectives, the following research questions were raised:

1. to what extend does Pragma- stylistics constitute as one of the main components of translating the Holy Qur'an into English?.

2. to what extend does Pragma- stylistics offer one of the most effective parameters according to which both the literary competence of the translator and religious and cultural awareness of the reader of the translation of the Holy Qur'an are revealed and gauged?

3. what are the difficulties that the translators of the Holy Quran encounter while translating the Qur'anic rhetorical expressions into English?

\section{RELATED LITERATURE}

\section{The Concept of Translation}

Translation can be defined as: "the placement of textual material in one language by equivalent textual material in another language". (Catford ,1990,p.78)

This definition vaguely refers to the textual material. It does not, however, clearly indicate as to whether the significance is more on the meaning or style or the linguistic elements like the words and sentence structures. Catford's 
work" A Linguistic Theory of Translation ( LTT)" primarily focuses around various processes of translation with special emphasis on the linguistic elements like phonetic, phonological, grammatical and lexical, graphalogical and other kinds of translation like complete vs. partial, total vs. restricted and the like. He also deals about transliteration. The argument of Catford cannot be underestimated, but the point of concern is that the outlook of Catford is very restricted and narrow and does not satisfactory fulfill the requirements of translation. More important in the process of translation in the conveying of message from one language to the other and the linguistic equivalence is secondary to the thematic equivalence. According to Newmark (1998, p.45):

Translation is such an art wherein the message conveyed through one language is replaced by the same message in the other language.

The examination of various definitions leads us to conclude that translation is such an art whereby the message in the text in one language is transferred into the text of another language. The limitations and constrains involved in the process of translation are of serious concern.

Halliday(1994,p.34), on the other hand, considers translation as"the relation between the text in the two languages involved,". According to him, the texts accomplish the same task under the same circumstances through the two different languages. He has no doubt aptly emphasized upon the significance of meaning. The aspects emerge out of a detailed examination of the viewpoints of various scholars of translation:

- Translation is a linguistic exercise that takes place between two languages.

- The language of the original text is called the source language and the language into which the translation is made is called the target language.

- The text in the target language is called the translated text.

- The process of transfer or re-establishment of the meaning from the source language into the target language is the essence of the art of translation.

- The expression between the SL and TL become synonymous. In other words, they convey the same meaning without distortion.

- Several aspects figure in the process of translation. They include the linguistic aspects, socio-cultural aspects and contextual aspects. A unique combination of all these aspects could result in a successful and meaningful translation.

- The sole aim of the translator is to successfully transfer the essence of the original text in the translated text.

Understanding of ' translation' could be considered in two contexts:

- In an extended context and

- In a restricted context.

Translation in the extended context is considered as the transfer of meaning in one symbolic constitution into the other symbolic constitution. "Symbolic constitution" refers to the structural nuances of the two languages. On the other hand, translation in the restricted sense is considered as the process that takes place between two languages. This primarily refers to the linguistic aspects and the applications of principles to the art of translation. In fact, translation becomes meaningful if any and only if it is considered both in the restricted sense as well as the extended sense.

The term, 'translation proper" means interlingual translation, translation within the same text), and it is in this sense that we have referred to translation so far. But sometimes the term is also used to refer to an intralingual translation (rewording), a process whereby a text in one variety of the language is reworded into another. This would be the case where the message of a text in, say, Old English (OE) is reworded into a text in modern English, or a text in one dialect or style is reworded into another. And we can speak of 'translation' when the replacement involves not another language but another, non-linguistic, means of expression, in other words a different semiotic system. In this sense we can say for instance that a poem is ' translated' into a dance or a picture, a novel into an operator a film. Such transmutations are examples of intersemiotic translation. (Jakobson, 1959/1990, p.232). What all these three processes have in common is that they involve the replacement of one expression of a message or unit of meaningful content by another in a different form.

There have been a number of theories of translation that have been debated about. They include:

i. Linguistic Theory.

ii. Universalist Theory.

iii. Relativist Theory.

While Catford(1991) is the proponent and authority on the linguistic theory of translation, Jakobson, 1959/1990, ) has proposed the universal and relativist theories. The theory of translation primarily deals with the linguistic aspects like the structural and lexical equivalences, formal correspondence, transference, transliteration, several types of translation like partial and total translation, phonological and graphalogical translation, translation shifts and the limits of translatability. (Kelly p.1997, p.60) as the name of the theory is indicative, the linguistic theory of translation is mostly concerned about the structure and less about the content/theme. Thus, the linguistic theory of translation fails to take care of the content aspect which is a serious setback to the art of translation. The reason is that the primary purpose of translation is to convey the content/theme from one language to the other without loss or distortion of the theme in the source language; thereby the significance of the thematic accuracy over-rides the linguistic accuracy. There is no exaggeration if it is argued that the linguistic accuracy in translation plays a secondary role. However, the linguistic 
aspects should not be made insignificant. It means that while utmost importance is given to the thematic accuracy, linguistic accuracy and correspondence between the SL and TL need to be maintained to the maximum possible extent. It follows that a good translation necessitates an ideal integration of the thematic transfer and linguistic transfer from the SL to TL. (Kelly, p.1997, p.61)

The Universalist theory according to Hewson and Martin is based on an extension of the economic concept of contractual transaction. (Kelly, p.1997, p.68).The term 'contract' refers to the act of translation. The term 'transaction' refers to the act of conciliation between the two languages and the unification established between them by the process of translation.( By unification is meant the establishment of one to one correspondence between SL text and the TL text not merely from the linguistic aspect but from the thematic aspect as well. According to Martin and Mason,(1997,p.45):

Translation, as a particular form of contract, is an agreement between the two LC is involved to transfer signification on a common convertibility basis in so far it is not detrimental to the specific differences between cultures. The fundamental notion both on the economic and on the translational planes is compromise; i.e., the agreement to remain separate in order to achieve a common goal.

The concept can be exemplified in stating that if the meaning can be generalized to the point of being transferred without major loss from one position to another, it follows that content is relatively independent of the form in which it has been expressed. It also means that socio-culturally determined differences do not constitute the essentials of communication. As these two aspects are highly differentiating and distinctive, they have to be sacrificed to achieve the transaction objective or the purpose of translation. It needs to be noted here that both content and structure go hand in hand in any verbal communication. They cannot be construed as watertight compartments. Logically, it can be clearly stated that language and content are interdependent and no content can be thought of in the absence of structure/language and no structure/language can be thought of without any content. They are so intensely inter-related that one cannot exist without the other. Therefore, in the event of sacrificing the socio-culturally determined differences or content do no justice to ensure the quality of translation and therefore, it does not appear to be reasonable to believe in sacrificing all these aspects.

A good translation or an ideal contract is possible within the scope of a single culture. Therefore, the Universalist conversion envisages the relationship between cultures as possible. But, necessarily, such relationship is only partial or flawed. (Cohen.1990,p.34). Some scholars, however, argue that in spite of diversity of cultures, there exists reasonable quantum of universals based on which the transaction or translation could be considered as reasonable and sufficient though the transaction/ translation excludes the total correspondence or one to one correspondence. They agree that the transfer of the deeper and wider interpretations between the two cultures gets precluded. (Cohen.1990, p.36)

In believing that cultural relationships are contractual transactions, translation can be conceived of as a process of transference based on the criterion of equivalence. Practically, this view boils down to the argument that a sound and reasonable compromise between the structural and thematic equivalences has to be ensured in good translation. Departing a little bit from this view, scholars like Hewson and Martin have preferred to argue that transference is necessarily partial and therefore, translation necessarily involves some loss. They, however, give a word of caution that this possible loss should be kept to the minimum and to the extent possible; it is to be compensated with the normalization of the common core. They conclude that translation consists in constantly perfecting the fundamentally uncontestable compromise.(Devey,1990,p.77).

The relativist theory is concerned with the concept of production within an interactive structure. From this point of view, common core or the universals are not only compressive as non-existence, but they contribute to "denaturing" of communication. The most important aspect in the art of translation is that the essential of signification lies in particulars and differences which can never be Universalist any way, but only exist in proportion to their specificity. It follows that signification can never be repealed, duplicated or transferred; it can only be reformulated and adapted to the ever changing conditions of meaning definition. The point to be taken note of in this context is that "meaning" is the most significant aspect in the art of translation. The act of producing the meaning intact in the language translated into besides the alterations in the factors involved in communication i.e., the medium or language adopted is essential. It is for this reason that constant adaptation is extremely significant and important in the context of translation. (Cohen.1990,p.67)

As stated above, perfect integration and correlation between the structure and content, expression and reality needs to be ensured which is associated with the concept of signification in the context of translation. Drawing the attention to these factors,

Martin and Mason (1997)call this process as "hermeneutic". Meschonnic conceives of translation as a unique combination of "rapport and tension". While rapport refers to a close correspondence between the SL and TL expressions, "tension" refers to the idiosyncrasies particularly in the context of aspects relating to culture. These aspects could be taken care of suitably to make the translation as perfect as possible only through exemplification and explanations of typical and unique cultural and social aspects etc. The exemplifications and explanations so required are called "complexification of perspective" Martin and Mason (1997, p.38).

Keeping in view the contradictions and variations between the above theories, Martin and Mason (1997) propose a "variational approach" to translation. They argue that the most crucial issue in the context of translation is the question of transferring information between cultures. Needless to mention that in spite of existence of universal features and 
commonalities across cultures, the differences and unique typical aspects relating to cultures which are specific to each community poses the real problem in the process of translation. The problem is not as intense as it is in the context of a normal simple text, which does not involve the typical and unique characteristics relating to culture, society etc. Thus, it may be noticed that the universal statements which are common all over do not pose any problems of serious concern in the process of translation. According to Martin and Mason,(1997,p.40)

Variation could indeed be defined as the set of all possible formulations that can be associated within given identifiable situations. Any partners at any moment have at their disposal sets of more or less interchangeable, more or less applicable formulations in various degrees of parafrastic nuances that they can be freely adjusted to their communicational objectives. Communication could, then, be conceived as the co-negotiated and contextually motivated selection of (more or less) "predictable communication formulation.

Exemplifying the context of "variation", they further state that:

- The participants in the act of communication have, at all times, some notion of the differences between the formulation options at their disposal and all their common core referential meaning. They are culturally constitutional, the variation range made up of variation options.

- They can relate these options to various contextual determinations or parameters that they can identify.

- The variation range is supposed to correspond to some segment of reality."

The above exemplification of the concept of "variation" leads us to infer that the linguistic formulation on the one hand is varied within certain limits while corresponding to a unique referent and on the other hand, it is strictly determined in terms of context while allowing for a second degree of formal predictability. Thus, the variational approach strikes a compromise between the cultural universals mentioned in the Universalist approach and the irreducible cultural differences in the relativist approach. These arguments boil down to the fact that the social and culture related aspects have to be translated within the permissible range of variation and that efforts to locate and find out "equivalences" would not be a useful exercise. These views of Martin and Mason concur with the earlier argument that in the context of translating/transferring, the cultural and social aspects can be meaningfully presented in the translation only with relevant details and explanatory notes.

The generative process and the variational approach refer to the paradigmatic and syntagmatic relations between and across languages that figure in the process of translation. Needless to state that these two kinds of relations are concerned with paraphrasing or interpretation. The normative process is concerned with the cultural equations and mediations and the socio-cultural norms. A unique combination of both generative and normative processes could result in a real good translation without much loss or distortion to the theme and meaning intended in the source language. The reasons offered in favor of the preference to the variational approach compared to the other theories of translation are that the generative and normative stages which are parts of the variational approach are supplementary to each other i.e., they strike a compromise between the linguistic factors and the non linguistic factors. This combination is an essential ingredient of a successful translation. The ideal combination between the two stages ensures the internal coherence between the SL text and the TL text. The variational approach to translation, as propounded by Hewson and Martin has been experienced by specialists in translation over a long period of time.

To come out with the sum and substance of this approach in arguing that it is a challenging task to correctly interpret and present aspects relating to non-linguistic factors like the societal and cultural factors and those relating to customs, habits, traditions, beliefs, myths and the like and that while the texts relating to these aspects are simply translated from SL to TL, the translated text can be made meaningful only by corresponding the context of situation. Otherwise, the translation loses all its significance as the intended sense gets lost.

The contribution of Martin and Mason to the discipline of translation is really appreciable as they have come out with the technical nuances as to how the explanatory notes and the contexts of situations could be integrated with the textual translations. It, therefore, follows that in order to arrive at a good translation, both the generative and normative processes have to be closely inter-related as otherwise the exercise involved in translation would not yield the expected results.

\section{METHODOLOGY}

This section describes the methodology that is used by the three researchers in collecting data of the current study . Methods

Descriptive qualitative method was used by the three researcher to collect data, and to fulfill the above-mentioned objectives

\section{RESULTS AND DISCUSSIONS}

Examples of Pragma-Stylistic Assessment of Some Selected Ayas of Surat Fatir فاطر( Creator, The Angles): 


\begin{tabular}{|c|c|c|c|}
\hline \multicolumn{4}{|c|}{ EXAMPLE 1} \\
\hline ST & $\begin{array}{c}\mathrm{T} 1 \\
\text { Abdel-Haleem }\end{array}$ & $\begin{array}{c}\mathrm{T} 2 \\
\text { Khan and Hilali }\end{array}$ & $\begin{array}{c}\text { T3 } \\
\text { Pickthall }\end{array}$ \\
\hline 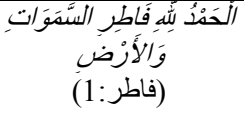 & $\begin{array}{l}\text { Praise be to God, Creator } \\
\text { of the heavens and } \\
\text { earth.( The Creator: } 1 \text { ) }\end{array}$ & $\begin{array}{l}\text { All praise and thanks are } \\
\text { Allah's ,the(only)Originator( or the } \\
\text { only Creator) of the heavens and } \\
\text { the earth( Fatir: } 1)\end{array}$ & $\begin{array}{l}\text { Praise be to Allah, the } \\
\text { Creator of the heavens } \\
\text { and the earth.( The Angles: } \\
\text { 1) }\end{array}$ \\
\hline
\end{tabular}

The word فاطر)(fatir ) has many different meanings in Arabic:

a. It means( creator) which means the following:

\begin{tabular}{|c|c|c|}
\hline 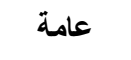 & البارِي؛ الفاطِر؛ الله؛ بارٍ (الباري) & The Creator \\
\hline اسلامية & 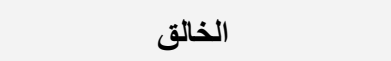 & The Creator \\
\hline 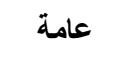 & المبدع : الله؛ خالق & creator \\
\hline قانونية & الفاعل؛ المورث؛ المؤلف & creator \\
\hline 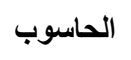 & 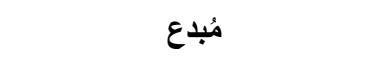 & creator \\
\hline سياسية & 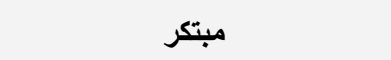 & Creator \\
\hline 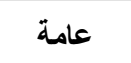 & مُصَتورُ الكَائنِات & the Creator of the Universe God \\
\hline
\end{tabular}

(http://www.almaany.com/ar/dict/ar-en/creator/)

The General Meaning of the Intended Ayah

The meaning of this ayah is (All the praises and thanks be to Allah), therewith, Allah; the Exalted praises and thanks His Honorable Own Self; the praises it is which refers the good description to Allah,( the (only) Originator [ or the( only) Creator of the heavens and the earth) without His having some example thereof to imitate (Tafisir AlJalalayn, Volume (2) :1245)

Abdel-Haleem and Pickthall rendered الحمد "alhamudu" as praise whereas Khan and Hilali's rendering was" praise and thanks". Khan and Hilali and Pickthall use transliteration النقحرة strategy to render Allah, this may result in better comprehension if the receptor is familiar with the word 'Allah"- the Muslim name for God- which has more divinity, whereas Abdel Haleem use the word" God" throughout his translation of the Surah. Khan and Hilali use the predeterminer "all' directly before the phrasal noun," praise and thanks", whereas Abdel-Hakeem and Pickthall omitted "all' in the beginning of the translated ayah.

Khan and Hilali and Pickthall use the definite article "the " before the noun' earth', whereas this article has been dropped by Abdel Haleem's renderings. The omitting of the definite article "the" is really confusing for the target language (TL) receptor. In the source text, the ال 'al' play a significant textual function but has been omitted in the TL by Abdel Haleem.

The three translators have translated فاطر fatir as" the Creator", therefore their renderings are accurate, appropriate, and relatively equivalent to the Quranic meaning of فاطر , but khan and Hilali took further step by using transliteration النقحرة thatir. To conclude, the three translations are not as informative as the original.

\begin{tabular}{|c|c|c|c|}
\hline \multicolumn{4}{|c|}{ EXAMPLE 2} \\
\hline ST & $\begin{array}{c}\mathrm{T} 1 \\
\text { Abdel-Haleem }\end{array}$ & $\begin{array}{c}\text { T2 } \\
\text { Khan and Hilali }\end{array}$ & $\begin{array}{c}\text { T3 } \\
\text { Pickthall }\end{array}$ \\
\hline 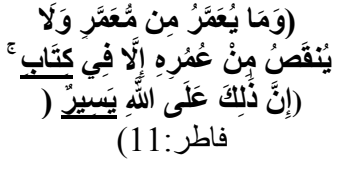 & $\begin{array}{l}\text { No person grows old or has } \\
\text { his life cut short, expect in } \\
\text { accordance with a Record: } \\
\text { all this is easy for God }\end{array}$ & $\begin{array}{l}\text { And no aged man is granted a } \\
\text { length of life nor is a part cut } \\
\text { off from his life ( or another } \\
\text { man's life), but is in a Book } \\
\text { ( Al-Lauh Al-Mahfuz),Surely } \\
\text { that is easy for Allah }\end{array}$ & $\begin{array}{l}\text { And no one growth old who } \\
\text { growth old, nor is aught } \\
\text { lessened of his life, but is } \\
\text { recorded an A Book. Lo! } \\
\text { That is easy for Allah. }\end{array}$ \\
\hline
\end{tabular}

Khan and Hilali and Pickthall rendered كنَّب "ketab" as "a Book" whereas Abdel-Haleem's rendering was "Record:".

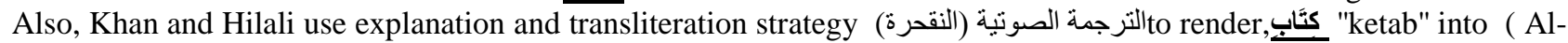
Lauh Al-Mahfuz),this may result in better comprehension if the receptor is not familiar with the word ", Abdel Haleem used (record) and therefore, his translation for the word كتَّب "ketab" is completely out of context. He used literal translation to render the meaning of this lexeme.

The word (yaseer) يَسير) is a polysemic word, which has two different meanings:

1. سهل Easy (Tafisir Al-Jalalyan: volume. 2 2009:1666).

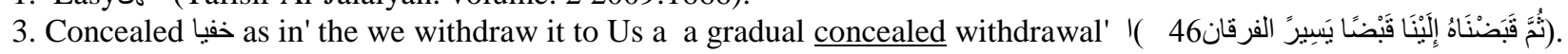


All the three translators have accurately translated the lexeme yaseer wَبَسيرِ which means in this context (easy).

\begin{tabular}{|c|c|c|c|}
\hline \multicolumn{4}{|c|}{ EXAMPLE 3} \\
\hline ST & $\begin{array}{c}\mathrm{T} 1 \\
\text { Abdel-Haleem } \\
\end{array}$ & $\begin{array}{c}\text { T2 } \\
\text { Khan and Hilali }\end{array}$ & $\begin{array}{c}\text { T3 } \\
\text { Pickthall } \\
\end{array}$ \\
\hline 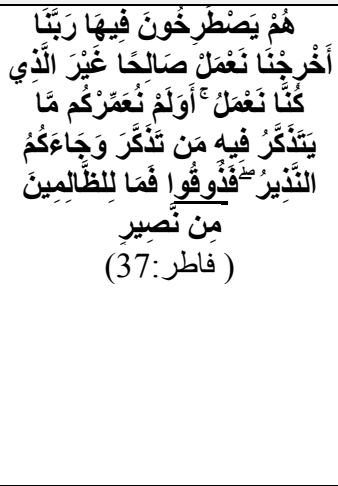 & $\begin{array}{l}\text { And they will cry out loud in } \\
\text { Hell, 'Lord, let us out; We } \\
\text { will do righteous deed - not } \\
\text { what we did before! did we } \\
\text { not give you a life long } \\
\text { enough to take warning if } \\
\text { you were going to?Did a } \\
\text { warner not come to you? } \\
\text { now taste (the punishment), } \\
\text { the evildoers will have } \\
\text { nobody to help } \\
\text { them.'(Fatir:37) }\end{array}$ & $\begin{array}{l}\text { Therein they will cry: "Our } \\
\text { Lord! Bring us out, we shall } \\
\text { do righteous good deeds, not } \\
\text { (the evil deeds) that we used } \\
\text { to do." (Allah will reply): } \\
\text { "Did We not give you lives } \\
\text { long enough, so that } \\
\text { whosoever would receive } \\
\text { admonition, - could receive } \\
\text { it? And the warner came to } \\
\text { you. So taste you (the evil of } \\
\text { your deeds). For the Zalimun } \\
\text { (polytheists and wrong-doers, } \\
\text { etc.) there is no helper." } \\
\text { (Fatir:37) }\end{array}$ & $\begin{array}{l}\text { And they cry for help there, } \\
\text { (saying): Our Lord! Release } \\
\text { us; we will do right, not (the } \\
\text { wrong) that we used to do. } \\
\text { Did not We grant you a life } \\
\text { long enough for him who } \\
\text { reflected to reflect therein? } \\
\text { And the warner came unto } \\
\text { you. then taste (the flavour of } \\
\text { your deeds), for evil-doers } \\
\text { have no helper.(Fatir:37) }\end{array}$ \\
\hline
\end{tabular}

The General Meaning of the Intended Ayah

The meaning of this ayah is (Therein they will cry) i.e. there in Hellfire, they will be crying out beseeching Allah, (Our Lord! Bring us out, we shall do righteous good deeds, not (the evil deeds) that we used to do." Means, they will be insistently praying to be brought back to the life of the world, so that they could perform deeds unlike ( the evils) they used to do before; yet, the Lord(Allah), may He be glorified, totally knows the fact that if he sent them back to the life of the world, they would go back to what they had been forbidden to do , and He knows that they are but lying; hence, to their beseech, He will not respond. This is why Allah says: (Did We not give you lives long enough, so that whosoever would receive admonition, - could receive it? And the warner came to you) meanings, " Have you not been granted such a life span that were you among those who benefit from the truth, you would have surely benefited from it during the span of life you were granted?". (So taste you (the evil of your deeds). For the Zalimun (polytheists and wrong-doers, etc.) there is no helper.) meaning." So.taste the torment of the Fire, as a punishment for your opposing the Prophets during your life span; for, verily, today you will have no helper to save you from the torment and fetters you are suffering. ( Tafisir Ibn Kathir ( Abridge) Volume (3): 1801)

The irony in all versions has translated literally. If we look at Abdel-Haleem's translation to the ironical lexical words

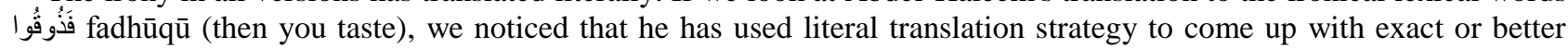
meaning. The same strategy Pickthall has used when translated the ironical lexical words (then taste you), into English uses literal translation, since according to him, translated the above ironical structure might come up with better

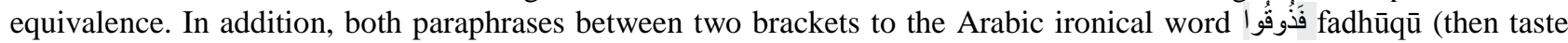
you) in three versions is different. If we look at Pickthal's paraphrases, we notice that he paraphrases the ironical word

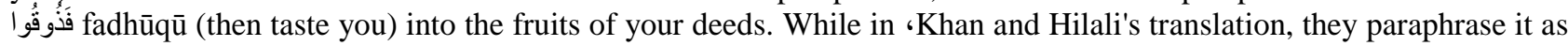
the flavour of your deeds. Syntactically, both translations resulted in different syntactic structures. If we look at Khan and Hilali's translation to the underlined ironical structure, it is found that the structure has started with the conjunction ,'so', which is an indication for the consequences of events, then followed by the verb' reflecting similar lexical irony as in the Arabic text. In addition, the verb 1 فَ fadhūqū is an order action set already by Allah to the unbelievers on the doomsday. This is unlike Abdel-Haleem's translation, where he also starts his translation with the adverb of time „now" an indication for the consequence of the events. Then the verbal sentence taste" as a verb order of the ironical structurel warnings. (Kadhim, 2000).

\section{CONCLUSIONS}

\section{A. Results in a Nutshells}

1. There are various instances where prgama -stylistic details are given in the Holy Quran. These prgama-stylistic expressions are usually rendered by literal rendering or performing transliteration. The translators are often unable to analyze these cultural terms and aspects of the Holy Quran and neither are they able to find the best and closest expressions to convey the same meaning and images.

2. It is extremely difficult to translate the Qur'an literally because the Arabic terms, expressions, and lexemes often have multiple literal meanings and are often used figuratively. In addition, many forms of Arabic lexical structures contain nuances of meaning that cannot be translated into another language owing to linguistic barriers. Therefore, the translations of the Holy Quran are largely based on interpretation, paraphrasing, and explanation of the source text.

\section{B. Implications and Recommendations for Future Research}


This study and other similar studies can play a role in enhancing the translational knowledge, understanding, and performance of students. Moreover, the study can support teaching Arabic to English translations in Arab universities. Students can potentially benefit from this study in the application of the knowledge of translational techniques and strategies to holy texts such as Qur'an.

\section{REFERENCES}

[1] Abdur-Razzaq ibn Hammam as -Sana'ni. Almusannaf.Beiut, Al-Maktab al-Islami.

[2] Ali, Abduaalh Yusuf. (1993). The Holy Quran, Maryland, USA: Amana Crop.

[3] Abdel-Haleem, M. (1999). Understanding the Qur'an: Themes and Style. New York: I.B. Tauris and Co. Ltd.

[4] Abdullah, A. (2003). Translations of Near Synonyms I the Quran:AContext -based Analysis. Unpublished master's thesis. London: University of London.

[5] Abdelwali, M. (2007). The Loss in the Translation of the Qur'an. Translation Journal, 11 (2), April. Retrieved 10 June, 2010 , from http://translationjournal.net/journal/ 40quran.htm.

[6] Abdul-Raof, H. (2001). Qur'ān Translation: Discourse, Texture and Exegesis. London: Routledge.

[7] Abdul-Raof, H. (2003). Conceptual and Textual Chaining in Qur'ānic Discourse. Journal of Qur'ānic Studies, 5 (2), $72-94$.

[8] Abū-Sayyideh, A. (2001). Synonymy, Collocation and the Translator. Turjuman, 10 (2), 53-71.

[9] Ahmed, M. (2001). Cognitive Bases of Translating Metonymy. Retrieved 20/9/2018http://www.google.com/search?hl=ar\&lr=\&biw=1259\&bih=551.

[10] Ahmed, Nazik, N. (2008). Translating Religious Text: An Investigation into English Translations of the Thirtieth Part of the Noble Quran. Unpublished PhD Thesis. Omdurman Islamic University.

[11] Akbar, M. (1988). The Meaning of the Qur'an. Lahore: Islamic Publications Ltd.

[12] Al-Azzam, B.H.S. (2005). Certain Terms relating to Islamic Observances: Their Meanings with Reference to Three Translations of the Qur'an and a Translation of Hadith. Boca Raton, Fl: Thesis.com.

[13] Al-Batal, M. (1985). The Cohesive Role of Connectives in a Modern Expository Arabic Text. Unpublished doctoral thesis. Michigan: University of Michigan.

[14] Al-Fakhari,A. "On Translation the Noble Quran. Journal of King Saud.Vol.2.3005; pp.67-68

[15] Al- Munjid (Arabic Dictionary).(1999). Beirut: Dar Al- Mashariq.

[16] Al-Sowaiddia, Belqees. (2011). Translating Near Synonyms in Holy Quran, unpublished Theses. Unpublished doctoral thesis. Michigan: University of Michigan.

[17] Ali, A. (1983). Word Repetition in the Qur'an - Translating Form or Meaning. Journal of Language and Translation, (Vol.6. (1999)19, 17-34. (Australia).

[18] Ali, M.Y. (1983). The Holy Qur'an: Text, Translation and Commentary (3rd ed., Vols. 1-3). Lahore: Sh. Muhammad Ashraf Publishers.

[19] Al-Kharabsheh, A. (2001). Translating Autoantonymy in the Qur'an. Across Languages and Cultures, 9 (1), 17-40.

[20] Al-Suyūțī, Jalāl al-Dīn. (1986). Al-Mazhar fī ulūm al-lughah al- 'Arabiyah. (M. Mawlā, A. al-Jawi and M. Ibrāhīm, Eds.). Baurit: Al-Maktabah al-'Asriyyah.

[21] Al-Zamakhsharī, Abū l-Qāsim. (1999). Al-Kashshāf 'an haqā’ iq ghawāmiḍ al-tanzīl. Beirut: Dār al-Ma rifah.

[22] Amos,F.R.(2004). Early Theories of Translation. London: Rutledge.

[23] Arberry, A. J. (1980). The Koran Interpreted (Vols.1-2). London: George Allen \& Unwin.

[24] Ayoub, M. (1992). The Qur'an and its Interpreters. (vol. 2). State University of New York.

[25] Aziz, Y. (1998). Topics in Translation with Special Reference to English and Arabic. Benghazi: University of Garyounis.

[26] Baker, M. (1992). In Other Words: A Course Book on Translation. London: Routledge.

[27] Badldinger K. (2001) .Semantics Theory. Oxford: Basisl Blackwell.

[28] Barnwell, K. (1999). Towards Acceptable Translation. Notes on Translation, 95, 19-25.

[29] Bassnett, S. (1980). Translation Studies. London: Routledge.

[30] Beekman, J. \& Callow, J. (1988). Translating the Word of God. Grand Rapids, Michigan: Zondervan.

[31] Bell, R.T. (1991). Translation and Translating: Theory and Practice. London: Longman.

[32] Benjammin, A.(1989). Translation . A New Theory of Words. London: Oxford University Press

[33] Blight, R. (2005). Footnotes for Meaningful Translations of the New Testament. Journal of Translation, 1(1), pp. 7-9..

[34] Bloor, T. \& Bloor, M. (1995). The Functional Analysis of English. London, New York, etc: Arnold.

[35] Cantarino, V. (1995). Syntax of Modern Arabic Prose: The Compound Sentence. Bloomington: Indiana University Press

[36] Catford, John C. (1990). A Linguistic Theory of Translation: An essay on applied linguistics, London: Oxford University Press.

[37] Cresswell, S. (1994). Content Analysis: Concepts, Methods and Applications. Nurse Researcher, 4(3), 5-16.

[38] Cohen, J.M. (1990). English Translators and Translations. London: Longman.

[39] Cook, G. (1999). Discourse Analysis. Oxford: Oxford University Press.

[40] Crystal, D. (1985). A Dictionary of Linguistics and Phonetics. Oxford: Basil Blackwell.

[41] Devey, C. (1999). Linguistics for Writers. Buffalo: SUNY Pres.

[42] Dickins, J., Sandor H. \& Higgins, I. (2002). Thinking Arabic Translation. A Course in Translation Method: Arabic to English. London: Routledge.

[43] Dixen.R.M.N. (1988). What is Language. London; Longman Gropu.LTM

[44] El-Awa, S. (2006). Textual Relations in the Qur'ān: Relevance, Coherence and Structure. London: Routledge.

[45] Elmarsafy, Z. (2009). Manifesto for a New Translation of the Qur'an: The Politics of "Respect" and the end(s) of Orientalism. Oxford: Basil Blackwell.

[46] Fatihi, A. (2003). Communication Dimension of Quranic Translation. New Delhi: Adam.

[47] Fawcett, P. (1997). Translation and Language: Linguistic Theories explained, Manchester: St Jerome.

[48] Finch, S.E. (1981). Contemporary Translation Theories. London: Edward Arnold. 
[49] Fromkin, V. \& Rodman, R.(1988). An Introduction to Linguistics. London: Routledge.

[50] Gülen, M. F. (2006). On the Holy Qur'an and its Interpretation. New Jersey: The Light.

[51] Gutt, E.A. (1991). Translation and Relevance: Cognition and Context. Oxford: Blackwell.

[52] Halliday, M. A. K. (1994). An Introduction to Functional Grammar. London: Edward Arnold.

[53] Harold,F. (2000) .Pragmatics. London: Routledge.

[54] Hatim, B. \& Mason, I. (1990). Discourse and the Translator. London: Longman.

[55] Hatim, B. \& Mason, I. (1997a). The Translator as Communicator. London: Routledge.

[56] Hatim, B. \& J. Munday. (2004). Translation: an Advanced Resource book. London: Routledge.

[57] Heidegger, M. (1997). On the Way of Translation. Battleboro, Vt.: Amana Books.

[58] Hervey, S. \& Higgins, I. (1992). Thinking Translation. A Course in Translation Method: French to English. London: Routledge.

[59] Hocksema, T. (1998). Differences in Translation. . London: Routledge.

[60] Hosni, A.M. (2004). On Translating the Qur'an: An Introductory Essay. Journal of King Saud University, 2(2), 93-134.

[61] House, J. (1990). Translation Quality Assessment: A model revisited. Tübingen: Gunter Narr.

[62] House, J. (2005). Text and Context in Translation. Journal of Pragmatics, (2006) 38, 338-358.

[63] http://www.thefreedictionary.com/tablets.

[64] http://www.thefreedictionary.com.

[65] http://www.jewishencyclopedia.com/view.jsp?artid=39\&letter=E.

[66] http://dictionary.cambridge.org/dictionary/british/swear_2.

[67] http://www.oxforddictionaries.com/view/entry/m_en_gb0620720\#m_en_gb0620720.

[68] http://www.britannica.com/EBchecked/topic/452123/perjury.

[69] http://www.oxforddictionaries.com/definition/evil?view=uk.

[70] http://www.wisegeek.com/what-is-niggardly.htm.

[71] http://www.englishtafsir.com/Quran/59/index.html.

[72] http://www.macmillandictionary.com/dictionary/british/barren.

[73] http://www.englishtafsir.com/Quran/51/index.html.http://www.englishtafsir.com/Quran/33/index.html.

[74] http://www.altafsir.com/index.asp.

[75] http://arthursclassicnovels.com/koran/koran_irving11.html (http://www.aijcrnet.com/journal/index/1128)

[76] Irving, T. B. (1985). The Qur'an: The First American Version. Battleboro, Vt.: Amana Books.

[77] Ibn Katheer, Isma'eel. (1988). Tafseer Al-Quran-Adheem. Beirut, Dar al-Marifah.

[78] Ibn Katheer, Isma'eel. (1998). Al-Bidayah Wa An -Nihayah, Dubai: Dar Abi Hayyan.

[79] Ibn Qayyim Al-Jawzeeyah. (1992). Zad Al-Ma'ad Fee Hady Khayral- Ibad .Beirut: Mu'assasah Ar-Risalah.

[80] Jakobson, 1959/1990, Jasper, D.(1993)(ed). Translating Religious Texts: Translation, and Interpretation. London: The Macmillan Company. Ltd.

[81] Johnstone, B. (1991). Repetition in Arabic Discourse, Paradigms, Syntagms, and the Ecology of Language. Amsterdam: John Benjamins Publishing Company.

[82] Kelly, L.G. (1997/2001). The True Interpreter: A History of Translation theory and practice in the West. Oxford: B. Blackwell.

[83] Kadhim,Karis Ameir. (2000) A Discourse Analytical Approach to Stylistic Variations Changes Employed in Arabic Translation. Retrieved 23 December, 2018, from https://www.researchgate.net/publication/328145462_

[84] Khalifa, M. (2005). Translation: Tried and True? Retrieved 20 August, 2018, from http://www.cyberistan.org/islamic/translate.htm.

[85] Khan, M.E. (2008) Approximation of the Meaning of the Holy Quran: A linguistic Analysis. Oxford: B. Blackwell.

[86] Koller, W. (1989). Equivalence in Translation. Harmondsworth: Penguin

[87] Kussmaul, P. (1995). Training the Translator. Amsterdam: John Benjamins Publishing Company.

[88] Larson, M.L. (1984). Meaning based translation: A Guide to Cross-language Equivalence. Lanham: University of Press of America.

[89] Leech, G. (1993). Semantics. Harmondsworth: Penguin.

[90] Levy, and Shreve. (2000). Pragmatics. London: Continuum.

[91] Lewis,R. (2005). Training the Translator. London: The Macmillan Company. Ltd.

[92] Laboner. (2008). Semantics. London: Continuum.

[93] Lockwood, A. (2001). Introduction to Stratification Linguistics. London: The Macmillan Company. Ltd.

[94] Lyons, J. (1998). Semantics. Vol.1\& 2 London: The Macmillan Company. Ltd.

[95] Makram, Ali.S. (1999). Mu'jam Al-Qiraa'at Al-Qur'aniyya.(1999). Tehran: Intisharat Uswa.

[96] Malinowski, B. (1923/1990). The Problem of Meaning in Primitive languages. In C.K. Ogden and I.A. Richards (Eds.), The meaning of meaning. London: Kegan Paul.

[97] Marlonr. J. (1988). Introduction to Translation. London: The Macmillan Company. Ltd.

[98] Martin, J. R. \& Rose, D. (2007). Working with Discourse: Meaning beyond the clause. London: Continuum)

[99] Martin and Mason, (1997). The Translator as A Communicator.Cambridge : Cambridge University Press.

[100] Matthiessen, C.M.I.M. (1999). The Environments of Translation. In Steiner, E. \& Yallop, C. (Eds.) Beyond content. Berlin: de Gruyter

[101] McCarthy, M. (1991). Discourse Analysis for Language Teachers. Cambridge: Cambridge University Press.

[102] Merriam-Webster (Ed.) (1995). Merriam-Webster's Dictionary of Synonyms: A Dictionary of Discriminated Synonyms with Antonyms and Analogous and Contrasted Words. Springfield: Merriam-Webster, Incorporated.

[103] Moore. A. (2001). "Semantics"-Meaning. Etymology and the Lexicon .from , Retrieved 27August, 2018, from http://www.cyberistan.org/islamic/translate.htm.

[104] Munday, J. (2005). Introducing Translation Studies. London: Routledge.

[105] Neubert, A. \& Shreve, G. (1990). Translation as Text. Kent: The Kent State University Press.

[106] Newmark, P. (1998). A Textbook of Translation. Hertfordshire: Prentice Hall. 
[107] Nida, E. (2001). Contexts in Translating. Amsterdam: John Benjamins Publishing Company.

[108] Norris,C. (1991). Deconstruction: Theory and Practice. Hertfordshire: Prentice Hall.

[109] Palmer, F. (1988). Semantics. Cambridge: Cambridge University Press.

[110] Panmna., L. (1982). "Homonymy and Polysemy. In Lingua.No58.pp.105-136.

[111] Ping, K. (1996). A Socio-semiotic Approach to Meaning in Translation. Babel, (42) 2, 289-300.

[112] Ping, K. (1999). Translatability vs. Untranslatability: A Sociosemiotic perspective. Babel, (45) 4, 289-300.

[113] Pitckhall, M. (2001). The Meaning of the Glorious Qur'an: An explanatory translation. London: George Allen and Unwin Ltd.

[114] Popovie, A. (1989). Dictionary for the Analysis of Literary Translation. Cambridge: Cambridge University Press

[115] Qurtubi, Mohammed ibn Ahmed. (1988). Al- Al-Jami'li Ahkam Al-Quran.Beirut: Dar Al-Kutub Al-'Illmeeyah.

[116] Richard, J. (1991). Longman Dictionary of Language Teaching and Applied Linguistics. Amsterdam: John Benjamins Publishing Company.

[117] Sadiq, S. (2008). Some Semantic, Stylistic and Cultural Problems of Translation with Special Reference to Translating the Glorious Qur'ân. Sayyab Translation Journal (STJ), 1, pp., 38-40.

[118] Scheliermacher, F. (1999). Translation Studies. Cambridge: Cambridge University Press.

[119] Shata, I. (1988). The Problems Involved in Translating Arabic Cognitive Synonyms into English. The Islamic University Magazine (Human Studies Series), 17(1), 869-890.

[120] Shunnaq, A. (1992). Functional Repetition in Arabic Realized Through the Use of Word-Strings with Reference to ArabicEnglish Translation of Political Discourse. Nouvelles De La Fit-Newsletter, 1(2), 5-39.

[121] Shunnaq, A. (1993). Lexical Incongruence in Arabic-English Translation due to Emotiveness in Arabic. TurjumÄn, 2(2), 37-63.

[122] Simms, K. (1993). Translating Sensitive Texts: Linguistic Aspects. Amsterdam: Rodopi.

[123] Simon, S. (1997). Gender in Translation. London: Routledge

[124] Snell-Hornby, M. (1988/1995). Translation Studies: An Integrated Approach. Amsterdam: John Benjamins Publishing Company.

[125] Steiner, G. (1998). After Babel: Aspect of Language and Translation. Amsterdam: John Benjamins Publishing Company.

[126] Stubbs, M. (1996). Text and Corpus Analysis. London: Routledge.

[127] Shawkani, Mohammed ibn 'Ali. (1993). Nayl Al-Watar,Cario: Dar Al-Hadith.

[128] Taylor, J. R. (2002). Near synonyms as Co-extensive Categories: 'High' and 'tall' revisited. Language Sciences, 25, $263-284$.

[129] Toury, G. (1990). The Nature and Role of Norms in Translation. In L. Venuti, (Ed.), The Translation Studies Reader. London: Routledge.

[130] Vinary J.and Darbelnet. (1995). Stylistics of French and English ( translated by Dider. London: Routledge.

[131] Widdowson, H. (1989). Introduction to Linguistics. Oxford: Oxford UP.

[132] Wills, W. (1982). The science of translation. Tubingen: Narr.

[133] World book dictionary online Retrieved 30August, 2018. http://www.thefreedictionary.com

[134] Yule, G. (2009). The Study of Language. Amsterdam: John Benjamins Publishing Company.

[135] Zhu, X. (2006). No Context, no Text: The Importance of Context in translation. Sino-US English Teaching, 3(9), 79-81.

[136]Zahir, M. (2008). The History of Translation. Translation Directory. Retrieved from 24/8/2018http://www.translationdirectory.com/articles/article1695.ph.

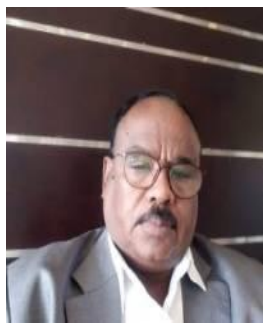

Ali Albashir Mohammed was born on 12th of June 1966. He obtained three PhDs in English literature, University of Khartoum (2003), PhD in translation, Omdurman Islamic University 2014 and PhD in Applied linguistics Sudan University of Science and Technology, 2018. Ali is a translator, translation expert and consultant and editor .Now Ali is working as a university professor at King Khalid University/ Kingdom of Saudi Arabia. Ali has published 20 books and 30 Articles in national and international journals.

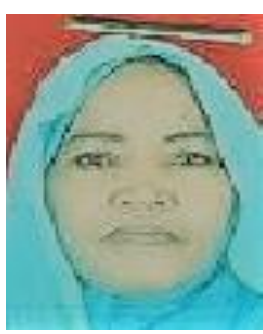

Majda Babiker Ahmed obtained her $\mathrm{PhD}$ in translation from Omdurman Islamic University 2015, and Master Degree from Nile Valley University in Applied Linguistics 2011. Now Majda is working as a university professor at King Khalid University/ Kingdom of Saudi Arabia. She is a freelance translator expert and editor. Majda published many articles national and international journals. 


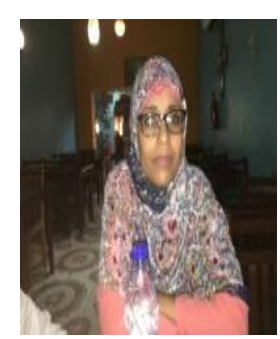

Dina Ali Abdullah Ali Currently, Dina is working as an assistant Professor, King Khaild University /College of Ahad Rufadi- English Department She is a freelance translator expert and editor. Dina published many articles national and international journals. 